DOI: 10.35757/RPN.2009.17.11

\title{
Barbara Korte, Sylvia Paletschek i Wolfgang Hochbruck, Der Erste Weltkrieg in der populären Erin- nerungskultur
}

Klartext, Esssen 2008, ss. 222.

Pierwsza wojna światowa pozostaje ważnym elementem europejskiej pamięci historycznej, ciągle także trudno jest mówić o istnieniu wspólnej, europejskiej pamięci o niej. Silne różnice widoczne są nie tylko między Europą Zachodnia Środkowo-Wschodnią i Południowo-Wschodnią i Stanami Zjednoczonymi, ale także między państwami zachodnioeuropejskimi. Redaktorzy książki rozpoczynają wstęp celnym opisem zdumienia grupy niemieckich studentów przed pomnikiem z czasów I wojny światowej we Francji. Powodem ich zdumienia jest fakt, że pomnik niezmiennie jest celem odwiedzin brytyjskich wycieczek szkolnych i turystycznych, podczas gdy w Niemczech wydarzenia lat Wielkiej Wojny zepchnięte zostały w niepamięć. Pamięć o I wojnie światowej jest niezmiernie ważną częścią pamięci historycznej w Wielkiej Brytanii, Kanadzie, Australii i Nowej Zelandii.

We wstępie redaktorzy książki podkreślaja, jak dynamicznym zmianom podlega pamięć o I wojnie światowej. W Niemczech została zmarginalizowana przez II wojnę światową, w skali europejskiej była długo całkowicie zdominowana przez pamięć o froncie wschodnim. W latach siedemdziesiątych i osiemdziesiątych uległa osłabieniu, aby nagle od lat dziewięćdziesiątych powrócić ze wzmocnioną siła, także jako część rosnącego zainteresowania historią. Myśl przewodnią książki stanowi ocena, że od tego momentu widoczna jest tendencja do ukształtowania pamięci o Wielkiej Wojnie jako wspólnym, europejskim miejscu pamięci, 
do którego odwoływać będzie się integrująca się i pacyfistyczna Europa. Oznacza to, że szczególne znaczenie zyskują doświadczenia wojenne o charakterze ponadgranicznym, a na znaczeniu traci dyskusja o winie za wybuch wojny (s. 11).

Z powyższego względu zrozumiałe jest zainteresowanie sposobem prezentacji I wojny światowej w kulturze masowej (telewizji, literaturze, filmie itd.), szczególnie ze względu na odwołanie do koncepcji pamięci kulturowej Jana Assmanna. Autorzy książki przyjmują że pamięć zbiorowa znajduje obecnie bardzo silnie wyraz $\mathrm{w}$ mediach i sposobie prezentowania historii w kulturze masowej (s. 13).

W zebranych w publikacji tekstach znajdujemy szerokie spektrum zagadnień. Część pierwsza obejmuje pamięć o Wielkiej Wojnie zachowaną w muzeach i pomnikach, przy czym te ostatnie tracą na znaczeniu, a te pierwsze - zyskują. Przedmiotem analizy jest Imperial War Museum w Londynie, Australian War Museum w Canaberze, z naciskiem na zbieżności i odmienności w koncepcjach kształtowania muzeów. Ze strony niemieckiej omówiona została przez Gerharda Hirschfelda sttutgardzka Weltkriegsbücherei, a Gerd Krumeich dokonał niezmiernie ciekawego opisu nowych tendencji w muzeach, na przykładzie francuskim i belgijskim. Część druga książki poświęcona jest popularyzacji Wielkiej Wojny w literaturze i komiksach: Na Zachodzie bez zmian Remarque'a, mit Richthofena w komiksach, brytyjski kryminał historyczny, australijskie książki dla dzieci i młodzieży o tej tematyce. Ostatni, trzeci rozdział obejmuje jako swego rodzaju wprowadzenie coraz popularniejsze Living histories des Ersten Weltkrieges, a przede wszystkim tematykę filmu kinowego (Horst Tonn o filmie w USA), telewizji (Matthias Steinle o I wojnie światowej w telewizji niemieckiej i francuskiej), do których dołączono turystykę związaną z pamięcią o I wojnie światowej. Zamknięcie książki stanowi ciekawy tekst, w którym Sylvia Paletschek analizuje, na podstawie filmu Merry Christmas, nawiązującego do bratnia się żołnierzy na froncie podczas świąt Bożego Narodzenia 1914 roku, nakładanie się $\mathrm{w}$ produkcji filmowej reżyserskiej koncepcji, współczesnych trendów postrzegania historii Wielkiej Wojny, motywacji politycznych oraz względów komercjalnych. 
Omawiana książka jest szczególnie istotna z polskiej perspektywy. W polskiej pamięci historycznej I wojna światowa dostrzegana jest przede wszystkim jako wydarzenie, które umożliwiło wybicie się na niepodległość. Równocześnie Polska musi być aktywnym uczestnikiem europejskiego dyskursu o historii, w którym Wielka Wojna staje się coraz bardziej wspomnianym miejscem pamięci, o bardzo odmiennym znaczeniu.

Piotr Madajczyk 